\title{
National symbols and nation-building in the post-apartheid South Africa
}

\author{
Elirea Bornman
}

\author{
Department of Communication Science, University of South Africa, P.O. Box 392, UNISA 0003, South Africa
}

Received 21 May 2005; received in revised form 6 July 2005; accepted 18 September 2005

\begin{abstract}
Symbols such as the Rainbow Nation and new national flag have been hailed worldwide as representative of optimism that the new political dispensation would bring reconciliation and unity in the diverse South African society. This article investigates issues of nation-building, national symbols and awareness of distinctive group membership in post-apartheid South Africa. The results of a survey in October/November 1998 involving a random sample of 2182 respondents are discussed. The sample was representative of all population groups, provinces and regions of South Africa. Language served as primary indicator of ethnic and/or cultural group membership. Although South Africans of all language and racial groups indicated pride in being South Africans, means for African Black groups were markedly higher than for other groups. African Blacks also identified the strongest with the new national symbols, while non-Blacks - especially Afrikaans-speaking Whites - rated them as less important. Only the new Constitution received high importance ratings from all groups. Analyses of variance with consciousness of distinctive group membership as dependent variable, indicated no significant differences for pride in being a South African. However, significant differences were found for identification with the various symbols - more consciousness of distinctive group membership was associated with less importance been attached to national symbols. It is concluded that the role of national symbols might be less important and that of civic elements such as the Constitution more important in promoting nationalism. Results are furthermore interpreted in terms of problems associated with nation-building in heterogeneous societies.
\end{abstract}

(C) 2005 Elsevier Ltd. All rights reserved.

E-mail address: bornme@unisa.ac.za. 


\section{Introduction}

Since the advent of a new democratic dispensation in South Africa in 1994, the metaphor of the "Rainbow Nation", first coined by Nobel peace laureate Archbishop Desmond Tutu, has become the symbol of peace and reconciliation among the country's diverse population with its long history of strife and conflict.

The Rainbow metaphor projects the image of different racial, ethnic and cultural groups being united and living in harmony. It has thus become a symbol of unity among the diverse population of South Africa. Other symbols of the new dispensation such as the new national flag and anthem have also become ubiquitous at national and international events reflecting expectations of national unity and a common South African identity (Habib, 1997; Möller, Dickow, \& Harris, 1999).

The new national flag was first used on 27 April 1994 (South African Government Information, n.d.). Its design and colours are a synopsis of South Africa's flag history. Although the flag's blaze of colour is widely regarded as its most conspicuous characteristic, governmental sources hold that the colours - green, black, white, gold, red and blue - have no universal symbolism and could hold different meanings for different people. On the other hand, the central design that begins with a V-form at the flag post that flows into a single horizontal band to the outer edge of the fly, symbolizes similar to the Rainbow Nation metaphor - the convergence of diverse elements in South African society taking the road ahead in unity (National Symbols of the Republic of South Africa, n.d.).

During the transitional period to a new political dispensation in 1994, the then State President proclaimed that South Africa would have two national anthems, namely Nkosi Sikelel' iAfrika and Die Stem (The Call of South Africa). Nkosi Sikilel' iAfrika (known in English as Lord Bless Africa) was composed in 1897 by Sontonga, a Methodist mission school teacher. The first stanza was originally written in Xhosa as a hymn. Seven additional stanzas were added later by a Xhosa poet, Mqhayi. This song become a symbol of the struggle against apartheid and was often sung as an act of defiance against the apartheid government (Arts \& Culture, n.d.; National Symbols of the Republic of South Africa, n.d.).

The Afrikaans version of The Call of South Africa was written in 1918 by the wellknown Afrikaans writer and politician, C.J. Langenhoven. In a similar fashion than the role played by Nkosi Sikilel' iAfrika during the apartheid era, this song became symbolic of the Afrikaner struggle against English dominance and was played by the South African Broadcasting Corporation together with God Save the King in the first decades of the 20th century. On 2 May 1957 both the Afrikaans and English versions were proclaimed as the official national anthem of the previous political dispensation (Arts \& Culture, n.d.; National Symbols of the Republic of South Africa, n.d.).

However, in 1996 a combined, shorter version of Nkosi Sikelel' iAfrika and The Call of South Africa was proclaimed as the national anthem of the post-apartheid South Africa. This version contains the complete first stanza of Nkosi Sikelel' iAfrica and the first part of the original first stanza of The Call of South Africa. However, the wording of the second part of The Call of South Africa was replaced by phrases emphasizing the ideal of unity among the South African population in striving for freedom.

A new Constitution was furthermore adopted by the Constitutional Assembly on 8 May 1996 and became law on 10 December 1996 (Constitution of the Republic of South Africa 
1996, n.d.). The process of drafting a new Constitution involved South Africans of all walks of life and was probably the largest public participation program ever carried out in this country. Political parties represented in the Constitutional Assembly negotiated the formulations of the text representing the integration of ideas from ordinary citizens, civil society and political parties. It is therefore stated that the Constitution is a representation of the collective wisdom of the people of South Africa and has been arrived at by general agreement. The founding provisions emphasize the unity of the South African state; human dignity; the equality of all people; the advancement of human rights and freedoms; non-racialism and non-sexism; the supremacy of the Constitution and the rule of law; as well as universal adult suffrage; a national common voters roll; regular elections and a multi-party system of democratic government.

The cornerstone of the Constitution is a Bill of Rights that enshrines the democratic values of human dignity, the equality of all people, common citizenship and freedom (Constitution of the Republic of South Africa 1996, n.d.). With regard to diversity, the Bill of Rights guarantees all South Africans freedom of association and the right to use the language and to participate in the cultural life of their choice. Individuals belonging to ethnic, racial or linguistic communities also have the right to enjoy their culture, practise their religion or use their language and to join associations and/or civil society organizations related to these interests.

It can hardly be denied that the metaphor of the Rainbow Nation, the new national flag and anthem as well as the Constitution have played a significant and decisive role in the transition to the new post-apartheid dispensation. Their apparent popularity gives the impression that they have indeed been successful in creating reconciliation, unity and new forms of nationalism. The metaphor of the Rainbow Nation has, for example, won popular appeal as a catch phrase that has been exploited for political ends as well as commercial enterprise. The new multicoloured national flag has furthermore been "banalized" by being painted on faces at sports meetings and printed and displayed on all kinds of consumer items such as bumper stickers, designs for caps, clothes, cars and all kind of curio's and traditional art. Overall it appears that South Africans of all racial, ethnic and language groups have been walking "tall" since 1994 and that national pride has surged to levels formerly unknown (Malan, 1998; Möller et al., 1999).

The promotion of new national symbols as well as the Constitution has been particularly important in the nation-building project, that is, in popularizing an overarching national identity and the formation of a new South African nation (Malan, 1998). It is noteworthy that, although the flag, national anthem and the Constitution all acknowledge diversity within South African society to some extent, the main emphasis of the symbolism and wording falls on the promotion of unity.

\subsection{The problematic issue of nation-building in heterogeneous societies}

The South African government is not at all alone in pursuing unity and emphasizing nation-building. According to Hanf (1989) many heterogeneous states opt for a policy of nation-building in order to overcome and avoid the manifold problems associated with heterogeneity and diversity. Nation-building strategies commonly pursue the "one state, one nation" ideal in attempting to create an overarching supra-national identity that should replace and/or subsume subnational identities and cultures (Bauman, 1998). 
However, Hanf (1989) distinguishes two forms of nation-building in terms of the recognition given to the existence of and provision for diversity and the existence of subnational cultures and/or identities. Partisans of Jacobinistic nation-building, on the one hand, regard loyalty to the state and the so-called state-nation as more important than loyalty to subgroups. The ideal of equality is furthermore not only interpreted in social and economic terms, but also implies cultural equality, that is the eradication of all forms of cultural differentiation. Syncretistic nation-building, on the other hand, gives recognition to ethnic, racial and other groupings as the building blocks of a larger unity and involves policies of multiculturalism that guarantee the cultural rights of ethnic or other minorities.

In many heterogeneous countries nation-building and the promotion of unity have become highly controversial. According to Mattes (1999), a lack of consensus about national identity can bring about a crisis of national legitimacy, that is a sense among certain sections of society that the defined national community is "inappropriate", that they are forced to be a member of it and that it is an inappropriate object of their loyalty. Plural societies may also inhibit popular consensus on the larger constitutional system and the nature of national symbols due to conflicting historical experiences and value systems. Those who perceive that their group is in power, will also identify much easier with the country, the state and its symbols, while groups on the periphery of power often feel marginalized. Plural societies thus often encounter difficulties in effecting a widely held sense of citizenship, that is loyalty to the state and the willingness to comply with the rules of citizenship.

Other analysts warn against attempts to build a nation based on a particular culture or set of values in a heterogeneous society (Degenaar, 1994; Horowitz, 1985; Liebenberg \& Duvenhage, 1996; Venter, 1999). Horowitz holds that nation-building projects often aim too high and that loyalties towards ethnic, cultural and other societal groupings have proved to be resistant against attempts to replace or subordinate them to loyalty towards an overarching national identity. He foresees that patriotism in a heterogeneous country would rather follow from attempts to accommodate rather than negate ethnic, cultural or other groups.

Instead of emphasizing nation-building, Jones and Smith (2001) hold that two dimensions of national identification should be distinguished. The first emphasizes birth or residence in a common territory, common citizenship and a common descent and culture. The second revolves around issues such as respect for national laws and institutions and national sentiment. These dimensions can also be interpreted in terms of the well-known distinction between the cultural and the political — or ethnic and civil aspects - of national societies. However, factor analyses of cross-national data brought Jones and Smith to the conclusion that a more effective discrimination between the cultural and the civic is necessary. The results of their study nevertheless suggest the ascribed or ethnic criteria for national membership to be the most important. Attempts to redefine national identity around civic themes, on the other hand, appears to meet with mixed success. While most of their respondents did regard civic attachment as important, this understanding of national identity did not relinquish ethnic-based understandings. On the other hand, the findings also suggest that the relationship between ascribed/ethnic and civic/voluntarist conceptualizations of national identity is not of a hydraulic nature. Thus a rise in one form does not necessarily lead to a fall in the other. 


\subsection{Nation-building in the post-apartheid South Africa}

As the metaphor of the Rainbow Nation, the new flag and national anthem as well as the preamble to the Constitution suggest, the new South African government led by the African National Council (ANC) has indeed been committed to a strategy of nationbuilding as is illustrated by the following quotation from a 1997 ANC discussion document:

However, the main thrust of the NDR [National Democratic Revolution] is not to promote fractured identities, but to encourage the emergence of a common South African identity. At the same time, it should be noted that some of the identities associated with "culture" or "ethnicity" or "religion" can in fact be contradictory to the building of a new nation that is based on principles of equity (ANC, 1997a, para. 32).

It is not without good reason that the ANC government has been pre-occupied with the issue of nation-building. Most analysts are unanimous of the opinion that South Africa can be regarded as a complex, divided and heterogeneous society characterized by deepseated racial, ethnic, cultural, language and religious differences overlapping with largescale socio-economic disparities (Horowitz, 1991; Human Sciences Research Council, 1987).

During the apartheid era South African society were legally divided into four population groups, namely Black Africans, Whites, Coloreds and Asians or Indians. Coloreds are defined as a non-White group of mixed racial descent - mainly descendants of the original Hottentot residents of the Cape at the time when the first White settlers arrived, Malay slaves imported during the early years of White settlement and White-Hottentot intermarriages during the era. It is furthermore not commonly known that South Africa also has one of the largest Indian populations living outside India (Human Sciences Research Council, 1987). This division is still used in official statistics published by Statistics South Africa (SSA). In a report on the results of the 2001 census, the racial composition of South Africa is reported to be as follows: Black Africans - 79.0\%; Coloreds - 8.9\%; Indians or Asians - 2.5\% and Whites - $12.1 \%$. In the preamble to the report it is stated, however, that independent demographic analyses of the census suggest an underestimation of the White population (SSA, n.d.).

Within the various racial groups there are also deep-seated differences due to divergent cultural, language and religious factors as well as historical experiences. Afrikaans- and English-speaking Whites are, for example, not only regarded as two different language and cultural groups, but the relationship between the two groups has also been characterized by the legacy of violent conflicts such as the Anglo-Boer War from 1899 to 1902 and increasing political polarization during the apartheid era (Human Sciences Research Council, 1987). Among African Blacks, nine languages are officially recognized, namely Sepedi, Sesotho, Setswana, siSwati, Tshivenda, Xitsonga, isiNdebele, isiXhosa and isiZulu (Constitution of the Republic of South Africa 1996, n.d.). These languages also represent groups with different cultures and traditions. Colonialization and apartheid has left South Africa even more divided than inherent differences as it accentuated racial, ethnic and class differences and set groups against other groups; not only Black against White, but also Black against Black, Colored against Indian, and so forth (Coetzee \& Wood, 1993). 
What is furthermore not often taken into account is that South African society is also characterized by large-scale civilizational differences. Historical processes have brought two main civilization paradigms in opposition in South Africa: the African and Western civilizations (Huntington, 1996; Venter, 1999). (Although groups belonging to the Islam and Hindu civilizations are also present, their influence on society has been limited due mainly to their relatively small numbers.)

According to the distinction drawn by Kymlicka (1995) between various sources of diversity, South Africa can furthermore be described as a multinational state. Kymlicka defines a multinational state as a state where more than one nation co-exists within the borders of the state. The term "nation" in this sense refers to a historical community with its own institutions sharing a distinct language and culture and occupying a given territory or homeland. Kymlicka contrasts multinational states with polyethnic states where cultural plurality is mainly due to individual and familial immigration where distinctiveness manifests mainly in family lives and voluntary associations. In contrast, nations or national minorities are usually characterized by a strong sense of their distinctiveness as a group from the larger society and their unique group identity as well as the striving towards some form of self-determination or autonomy. That does not mean that national minorities do not have some form of loyalty to the larger political community. However, Kymlicka believes that the loyalty of nations or national minorities to the state should be typified as forms of patriotism, namely feelings of allegiance to a state, rather than identification with a supranational identity.

Current forms of cultural plurality in South Africa cannot be ascribed to recent immigration. On the contrary, various forms and degrees of group awareness can be distinguished. Afrikaans-speaking Whites or Afrikaners can, for example, be described as a national minority. Afrikaners is a self-conscious community whose identity is not only vested in their culture and language, but is also associated with a strong sense of a common history and destiny within South Africa as homeland. Over the years the group has also established cultural, religious and other institutions to support their identity. Among African Black language groups a self-conscious sense of cultural identity has been embraced as well as rejected. Although research indicates a strong sense of language and cultural awareness among some Black language groups (Bornman \& Olivier, 2000), as well as a sense of identification with homelands such as Zulus in KwaZulu-Natal, the emphasis on language and cultural divisions during the apartheid era has contributed towards the denial of ethnicity especially among urban Black communities (Human Sciences Research Council, 1987). Black groups have also not developed strong institutions to support their language, culture and identity. Research furthermore indicates lower levels of ethnic identification among Coloreds and Indians or Asians than is the case for Afrikaansspeaking Whites and some African Black language groups (Bornman \& Olivier, 2000).

Unfortunately, it is not clear what the new South African government understands under the concept "nation" in its emphasis on nation-building (Venter, 1999). Since its foundation in 1912 the ANC has followed a non-ethnic and non-racial approach towards South African nationalism. On the other hand, with the use of the metaphor of the Rainbow Nation with its harmonious blend of colours, it appears to acknowledge and accommodate the existence of racial, ethnic, cultural and other differences within a unified South African nation. However, the above quotation from the 1997 discussion document gives the impression that subnational identities should be suppressed in favour of a 
common national identity. Rather than diversity, the following quotation from another discussion document emphasizes Africanism, also embodied in the concept of an "African Renaissance" promoted especially by President Mbeki (in ANC, 1997b, para. 44):

But it is critical that the overarching identity of being South African is promoted among all those who are indeed South African, as part of a process of building an African nation on the southern tip of the continent. The affirmation of our Africanness as a nation has nothing to do with the domination of one culture or language by another — it is recognition of a geographic reality and the awakening of a consciousness which colonialism suppressed (ANC, 1997b).

Nation-building strategies in South Africa have been criticized by various analysts. Degenaar (1994) objects against the mere use of the term nation-building in a country like South Africa as it encourages an emphasis on uniformity, while diversity and individuality should rather be respected. Venter (1999) holds that a civil national identity, as distinguished by Jones and Smith (2001), should be emphasized instead of uniformity. Thus, South African patriotism should be fostered by promoting loyalty towards the Constitution (a social contract) and the country (a particular territorial space).

\subsection{Research pertaining to nationalism and national symbols in South Africa}

Möller et al. (1999) report on a number of empirical studies on the nature of patriotism and nationalism in South Africa after the advent of a new political dispensation. In a survey conducted in 1994 it was found that a majority of $65 \%$ of all South Africans supported the notion of the Rainbow Nation, although Whites were less supportive than other groups. However, 2 years later, in 1996, support had dropped to $48 \%$ with the most significant drop among Indians, while the highest levels of support were found among African Blacks and Coloreds. Support was furthermore associated with political affiliation. In 1994, supporters of the ANC and National Party (NP) were most likely to be Rainbow Nation supporters also, but in 1996 supporters of the NP could be divided in supporters and opponents of the Rainbow Nation concept. Resistance against the symbolism of the Rainbow Nation were most conspicuous among supporters of the Inkatha Freedom Party (IFP - a Zulu ethnic-based party) and the liberal Democratic Party (DA) with mostly White supporters. The 1996 study furthermore indicated that support for the Rainbow Nation symbolism went hand in hand with national pride and feelings of closeness to other South Africans.

Möller et al. (1999) also investigated feelings of national pride in surveys conducted in 1995 and 1996. Although the question format differed for the two studies, a decline in national pride could be detected. Whereas a vast majority of South Africans $(83 \%)$ indicated in 1995 that they felt very proud to be South Africans, only 65\% indicated in 1996 that they very often or often felt proud of being South Africans. In both studies expressions of national pride were more pronounced among African Blacks and ANC supporters, while lower levels of pride were recorded in 1996 among supporters of ethnicbased parties such as the IFP, the Conservative Party and Freedom Party (both orientated towards Afrikaner ethnic interests). 
The question on national pride in the 1996 study was followed by a question probing sources of national pride such as sporting achievements, the national flag and anthem, reconciliation and unity as symbolized in the Rainbow Nation concept, the Truth and Reconciliation Commission, the Constitution and Bill of Rights, and world acceptance (Möller et al., 1999). The symbol of the Rainbow Nation held the highest appeal and attracted the highest percentage of African Black votes, the second highest percentage of Colored and Indian votes and the third largest percentage of White votes. However, the results also suggest that national pride could be experienced in different ways by various South African groups. While the Rainbow Nation option was favoured by middle and lower income groups and supporters of the ANC and IFP, sports achievements and world acceptance were emphasized by Whites and more affluent groups. Supporters of the liberal Democratic Party were also less likely to support the Rainbow Nation notion. Low income groups and Blacks were more likely to select the Reconciliation and Development Programme and the national flag and anthem, whereas the Constitution and Bill of Rights appealed to a minority of predominantly younger people.

A further indication that a concept such as "national pride" could be interpreted differently by various groups, can be found in a study conducted among South African students by Heaven, Stones, Simbayi, and Le Roux (2000). The fact that self-identified White Afrikaner students associated national strength and order (that is the desire for national greatness, national security and national economic development) with the Afrikaans language, indicates a strong ethnic interpretation. The responses of selfidentified Black Africans, on the other hand, imply a more encompassing perception of South African nationalism and an acknowledgement that national identity subsumes differences in language, race and class. Heaven et al. conclude that these different interpretations are a reflection of different social contexts, life experiences and ideological objectives.

The aim of this study was to obtain an understanding -5 years after the advent of a new dispensation - of the extent of national pride among various South African racial, ethnic and language groups, the importance attached to particular national symbols and cultural concepts as well as the relationship between national pride, ratings of the importance of various symbols and cultural concepts as well as a sense of belonging to a distinctive community. On the basis of the literature and previous research, the following hypotheses can be stated:

Hypothesis 1. African Black groups that are currently in power, will show greater pride in being South Africans than White, Indian and Colored groups that are further removed from the seats of power in the new political dispensation.

Hypothesis 2. Similar than for pride in being South Africans, African Black groups will identify more with the symbols and cultural concepts associated with the new political dispensation in South Africa than White, Indian and Colored groups.

Hypothesis 3. Groups with a strong sense of distinctiveness will show less pride in being South Africans and will attach less value to the symbols and/or cultural concepts associated with the new dispensation. 


\section{Method}

\subsection{Nature of the study}

A number of questions on national pride, the importance attached to particular symbols and/or cultural concepts as well as a sense of belonging to a distinctive community were included in an omnibus questionnaire survey conducted during November/December 1998 by Market Research Africa (a private research organization) on behalf of the Human Sciences Research Council (HSRC). At the time of the study more than 4 years had passed since the advent of a new political dispensation in South Africa and the country stood on the brink of the second general elections in 1999.

A multistage stratified cluster sampling design was employed to draw the sample. The original sampling design made provision for 2200 respondents. Stratification in the sampling design aimed at the proportionate representation of all racial groups, provinces, the former so-called homelands as well as rural and urban areas. Census enumerator areas served as clusters. Within the randomly selected enumerator areas, households were systematically selected, while a respondent within a selected household was chosen by means of a selection grid. If no suitable respondent could be found in a particular selected household, this household was replaced by a household directly to its left or right side. Questionnaires were completed by means of personal interviews conducted by interviewers trained by personnel of Market Research Africa and the HSRC. Questions were set in Afrikaans and English, but the fieldworkers were trained to explain the meaning of questions in vernacular languages when necessary.

The final realized sample consisted of 2182 respondents of 18 years or older - a response rate of $99.2 \%$. The final realized sample consisted of $67.5 \%$ African Blacks, $9.3 \%$ Coloreds, 3.2\% Indians or Asians and 20.0\% Whites. Speakers of various languages were represented as follows: Afrikaans - 22.5\% (it has to be kept in mind that the majority of Afrikaners as well as Coloreds are Afrikaans-speaking); English - 10.5\%; other European languages - 0.4\%; Sesotho - 9.7\%; Setswana - 10.1\%; Sepedi - 8.2\%; Seswati $3.1 \%$; isiNdebele - 0.8\%; isiXhosa - 14.9; isiZulu - 15.5; Xitsonga/Shangaan - 1.7; Tshivenda/Lemba $-2.2 \%$; and other languages - $0.1 \%$. The final realized sample furthermore consisted of $43.7 \%$ male and $56.3 \%$ female respondents. The age composition was as follows: $18-25$ years $-18.3 \% ; 26-35$ years $-22.6 \% ; 36-45$ years $-22.5 \%$; $46-55$ years $-14.0 \%$; 56-65 years $-12.1 \%$; respondents of 66 years and older $-10.4 \%$.

\subsection{Measurement of pride in being a South African}

Respondents had to rate their pride in being a South African on a five-point Likerttype scale. The wording of the question was as follows: "How do you feel to be called a South African? Are you very proud, proud, uncertain, not very proud or not proud at all?"

This wording resembled that of a question included in various Euro Monitor surveys. The highest possible mean score was 5 and the lowest possible score 1 with higher scores indicating more pride in being a South African. As the midpoint of the scale was 3.0, scores below 3.0 are an indication of a lack of pride in being a South African, while the opposite is true for scores above 3.0. 


\subsection{Measures of the importance attached to national symbols}

Respondents' ratings of the importance attached to five prominent national symbols and cultural concepts were furthermore investigated, namely the metaphor of the Rainbow Nation; the cultural concept of an African Renaissance; the South African Constitution; the new South African flag; and the new national anthem.

The wording of the question was as follows: "This question deals with a number of symbols that can play a role in the forming of the identity of South Africans. I am going to read you a list of symbols or cultural practises. Please indicate how important or unimportant EACH OF THEM are for you[r], or people like you, OWN sense of identity."

The importance attached to each symbol was measured on 5-point Likert-type scales with the following response possibilities: very important, reasonably important, uncertain, reasonably unimportant and totally unimportant. The highest possible mean score was consequently also 5 and the lowest possible score 1. A higher score (at least above 3.0) is an indication that more importance was attached to the particular symbol or concept, while the opposite is true of lower scores and especially of scores below 3.0.

\subsection{Measurement of a sense of belonging to a distinctive community}

The wording of a question aimed at measuring respondents' consciousness of their membership of a distinctive cultural community was as follows: "Do you consider yourself to belong to a distinctive community with its own distinctive culture?" A similar question was used by Mattes (1995) in a post-election survey conducted by the Institute for a Democratic South Africa (IDASA) in 1994. Provision was made for three response possibilities, namely yes, no and uncertain/do not know.

\subsection{Analyses of the data}

The data were analysed by means of Statistical Analysis System (SAS ) and Statistical Package for the Social Sciences (SPSS) programs. Mean scores were calculated for the measurements of national pride and importance attached to national symbols and cultural concepts. As language was identified as one of the most important sources of identification among South Africans (Bornman \& Olivier, 2000), separate mean scores were calculated for the various South African language groups. Owing to the categorical nature of the question, frequencies were calculated for the question regarding membership of a distinctive community. One-way analyses of variance (ANOVAS) were performed with pride in being a South African and identification with national symbols and cultural concepts as dependent variables. The independent variable was consciousness of being a member of a distinctive community with a distinctive culture.

\section{Results}

\subsection{Mean scores for pride in being a South African}

The mean scores for this variable are reported in Table 1. The mean scores for all the language groups were 4.0 or higher - an indication that the majority of the sample were very proud to be South Africans. 
However, the mean scores for the African Black ethnic and/or language groups were throughout higher than for any of the other groups. The lowest mean score was obtained for the English-speaking Whites and the second lowest mean for the Colored respondents. The mean score of 4.3 for the Afrikaans-speaking Whites - although lower than the scores for the Indian and African Black language groups - can still be regarded as an indication of a high degree of pride in being a South African.

\subsection{Mean scores for ratings of national symbols}

According to the mean scores for the importance attached to various national symbols and cultural concepts (Table 1), the ratings of the African Black language groups for all five symbols and cultural concepts were 4.0 or higher with the only exception the mean rating of 3.9 given by the Tshivenda/Lemba-speaking respondents to the idea of an African Renaissance. In contrast, relatively lower mean scores were obtained for the Coloreds, Indians/Asians and the two White groups and especially for the Afrikaans-speaking Whites.

Despite the fact that the Afrikaans-speaking Whites voiced relatively strong pride in being South Africans, noteworthy low ratings were obtained for this group for most of the national symbols and cultural concepts investigated. In fact, the mean ratings for the Afrikaans-speaking Whites were the lowest for all five symbols and concepts. The ratings of 2.4, 2.2, 2.4 and 2.5 for the metaphor of the Rainbow Nation, the concept of an African Renaissance, the South African flag and the national anthem respectively can be interpreted as non-identification with and/or alienation from these symbols and concepts.

The English-speaking Whites also rated the idea of an African Renaissance as not very important, while the corresponding mean scores for the Colored and Indian/Asian respondents were also relatively lower. It appears that the idea of an African Renaissance did not appeal to other South African groups in a similar way than to African Blacks.

The only symbol that was rated relatively high by all groups was the South African Constitution. The conclusion can be drawn that the Constitution is regarded as an important symbol of South Africa and a major factor that binds citizens of all ethnic and racial groups together.

\subsection{Frequency analysis of the question measuring consciousness of membership of a distinctive community}

Table 2 gives the frequencies of responses on the question measuring a sense of membership of a distinctive community. The highest level of awareness of membership of a distinctive group was found among the Afrikaans-speaking Whites - $89.2 \%$ of this group gave a yes response and only $7.9 \%$ a no response. There was also little uncertainty among members of this group about this issue as only $2.1 \%$ indicated that they did not know. However, the Afrikaans-speaking Whites were not the only group that indicated a high level of consciousness of their distinctiveness. High percentages of Indian/Asian as well as Shangaan/Tsonga respondents also gave positive responses - $84.8 \%$ and $82.3 \%$, respectively. More than two-thirds of the Seswati-speaking (73.5\%), Sesotho-speaking (71.1\%), Zulu-speaking (71.1\%) and Xhosa-speaking (69.5\%) respondents also gave yes responses to this question. 


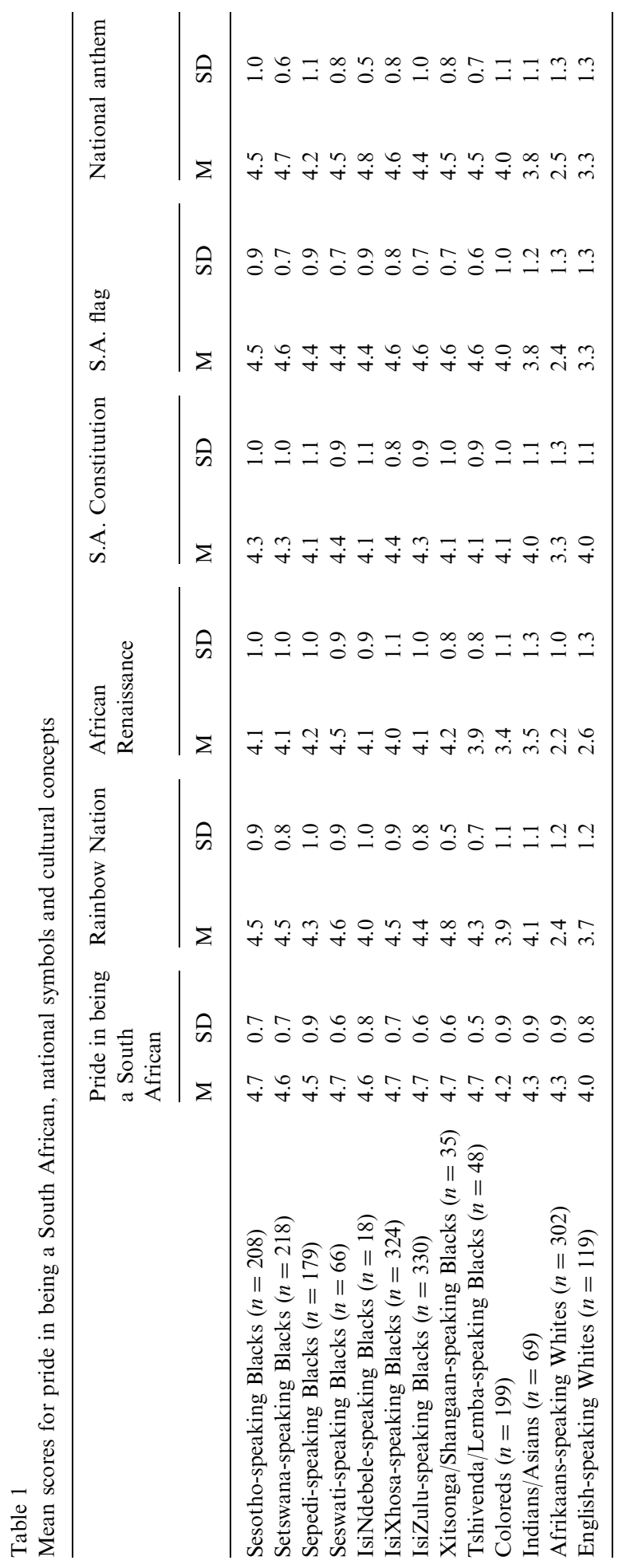


Table 2

Responses on the question "Do you consider yourself to belong to a distinctive community with its own distinctive culture?"

\begin{tabular}{|c|c|c|c|c|c|}
\hline & No response & Yes & No & Don't know & Total \\
\hline Sesotho-speaking Blacks $(n=208)$ & 0.5 & 71.1 & 25.2 & 3.2 & 100.0 \\
\hline Setswana-speaking Blacks $(n=218)$ & 0.7 & 48.9 & 47.2 & 3.3 & 100.1 \\
\hline Sepedi-speaking Blacks $(n=179)$ & 0.0 & 56.4 & 35.5 & 8.2 & 100.1 \\
\hline Seswati-speaking Blacks $(n=66)$ & 0.0 & 73.5 & 19.9 & 6.5 & 99.9 \\
\hline IsiNdebele-speaking Blacks $(n=18)$ & 0.0 & 55.5 & 16.3 & 28.1 & 99.9 \\
\hline IsiXhosa-speaking Blacks $(n=324)$ & 0.0 & 69.5 & 25.4 & 5.0 & 99.9 \\
\hline IsiZulu-speaking Blacks $(n=330)$ & 2.5 & 71.1 & 25.0 & 1.5 & 100.1 \\
\hline Xitsonga-speaking Blacks $(n=35)$ & 2.7 & 82.3 & 8.4 & 6.6 & 100.0 \\
\hline Tshivenda/Lemba-speaking Blacks $(n=48)$ & 0.0 & 16.8 & 22.9 & 60.3 & 100.0 \\
\hline Coloreds $(n=199)$ & 0.0 & 51.0 & 36.5 & 12.5 & 100.0 \\
\hline Indians/Asians $(n=69)$ & 0.0 & 84.8 & 13.3 & 2.0 & 100.1 \\
\hline Afrikaans-speaking Whites $(n=302)$ & 0.8 & 89.2 & 7.9 & 2.1 & 100.0 \\
\hline English-speaking Whites $(n=119)$ & 0.9 & 45.7 & 50.6 & 2.7 & 99.9 \\
\hline
\end{tabular}

The lowest levels of consciousness of membership of a distinctive group were found among the Tshivenda/Lemba-speaking (16.8\%); English-speaking White $(45.7 \%)$ and Setswana-speaking respondents $(48.9 \%)$. It is furthermore of interest that almost two-thirds of the Tshivenda/Lemba-speaking respondents gave a don't know response.

\subsection{Results of one-way of analyses of variance}

The results of one-way analyses of variance are reported in Table 3. As mentioned in Section 2.5, the dependent variables were pride in being a South African as well as identification with the various symbols and/or concepts investigated in this study. Especially noteworthy is the fact that no statistical significant differences were found between the three response options (yes, no and don't know) of a sense of being a member of a distinctive community for pride in being a South African. In contrast, statistically significant $F$-values were found for all the various symbols and/or cultural concepts. In the case of all five symbols and/or concepts post hoc Scheffe tests indicated that those respondents who responded positively to the question regarding membership of a distinctive community identified significantly less with the five symbols and/or concepts than those respondents who responded negatively. In the case of the Rainbow Nation as dependent variable, respondents who responded negatively to the question on membership of a distinctive community, also identified significantly more with this symbol than those who were uncertain or did not know. A similar tendency was observed for the importance attached to the South African Constitution. Respondents that gave a yes response on the question on consciousness of membership of a distinctive community rated the national anthem furthermore as significantly less important than those who gave a don't know/ uncertain response. 
Table 3

Analysis of variance with consciousness of membership of a distinctive community as independent variable

\begin{tabular}{|c|c|c|c|c|}
\hline & df & SS & MS & $F$ \\
\hline \multicolumn{5}{|c|}{ Pride in being a South African } \\
\hline Between groups & 2 & 2.49 & 1.24 & \multirow{2}{*}{1.99} \\
\hline Within groups & 2149 & 1345.35 & 0.63 & \\
\hline \multicolumn{5}{|l|}{ Rainbow Nation } \\
\hline Between groups & 2 & 43.37 & 21.69 & \multirow[t]{2}{*}{$15.52^{* *}$} \\
\hline Within groups & 2155 & 3010.80 & 1.40 & \\
\hline \multicolumn{5}{|l|}{ African Renaissance } \\
\hline Between groups & 2 & 14.79 & 7.39 & \multirow[t]{2}{*}{$4.59^{*}$} \\
\hline Within groups & 2155 & 3473.65 & 1.61 & \\
\hline \multicolumn{5}{|l|}{ SA Constitution } \\
\hline Between groups & 2 & 19.06 & 9.53 & \multirow[t]{2}{*}{$8.50^{* *}$} \\
\hline Within groups & 2153 & 2415.19 & 1.12 & \\
\hline \multicolumn{5}{|l|}{ SA flag } \\
\hline Between groups & 2 & 31.71 & 15.86 & \multirow[t]{2}{*}{$11.02^{* *}$} \\
\hline Within groups & 2154 & 3099.66 & 1.44 & \\
\hline \multicolumn{5}{|l|}{ SA national anthem } \\
\hline Between groups & 2 & 47.92 & 23.96 & \multirow[t]{2}{*}{$15.82^{* *}$} \\
\hline Within groups & 2155 & 3264.23 & 1.52 & \\
\hline
\end{tabular}

${ }^{*} p<0.05$.

${ }^{* *} p<0.01$.

\section{Discussion}

The results of this study, as well as those of comparative studies conducted within the South African context (Heaven et al., 2000; Möller et al., 1999), serve as an illustration of the difficulties encountered by governments in heterogeneous and deeply divided societies. Not only is it extremely difficult to foster unity and an overarching national identity, but it is even more difficult to introduce national symbols that would appeal to all racial, ethnic, cultural and language groupings.

In the first instance, the results confirmed Hypothesis 1 as it was found that most African Black groups indicated notably higher levels of pride in being a South African than the non-Black Colored, Indian/Asian and White respondents. A similar tendency was reported by Möller et al. (1999). It appears that the new political dispensation that brought an African Black government into power has strengthened the identification of all Black African language groups with South Africa, while the groups that did not hold as much political power indicated lower levels of pride in being a South African.

However, as relatively high mean scores (4.0 and higher) were found for all the groups investigated, the results also confirmed the conclusion drawn by Möller et al. (1999) that there do exist some kind of national pride among South Africans of all racial, ethnic and/ or cultural groups. The question that needs to be answered is whether these levels of pride in being a South African can be ascribed to the fulfilment of the aims of nation-building, 
namely the formation of an overarching and unitary national identity and common nationhood, or should rather be regarded as forms of patriotism or territorial allegiance (Kymlicka, 1995) and/or differential interpretations of a South African identity (Heaven et al., 2000; Jones \& Smith, 2001).

Despite the widescale international coverage given to the introduction of the Rainbow Nation metaphor and symbols such as the new flag as well as their widescale use and apparent popularity, the importance ratings for the Rainbow Nation metaphor, the concept of an African Renaissance, the new national flag and anthem also confirmed Hypothesis 2. Most of the African Black language groups attached more importance to the national symbols and/or cultural concepts investigated in this study than the White, Indian/Asian and Colored groups that were further removed from the seats of power. A possible explanation could be that, despite all the good intentions of promoting unity in the design of the new symbols, they are increasingly perceived as symbols representing the African Black-dominated government rather than being representative of a general and overarching South African patriotism.

The lowest importance ratings for all five symbols investigated were recorded for the White Afrikaans-speaking respondents. In fact, the ratings of this group for the metaphor of the Rainbow Nation, the concept of an African Renaissance, the new South African flag and the national anthem could be interpreted as negative identification with or alienation from these symbols. It could be argued that Afrikaans-speaking Whites, and to a lesser extent also other non-Black groups, felt that their particular cultural and other interests were no longer served by the Black-dominated government. Feelings of alienation towards the symbols representing the "new" South Africa among Afrikaans-speaking Whites could furthermore have been aggravated by the fact that they identify closely with Western civilization and its values, while the current South Africa is associated with Africanism as reflected in the promotion of and emphasis placed on the concept of an African Renaissance.

These findings are probably also a further confirmation of the tendency identified by Möller et al. (1999) of the dwindling popularity of the major national symbols since the first years of the new political dispensation especially among non-Black groups. During and shortly after the advent of a new political dispensation, national pride and support for the new national symbols were probably bolstered by various factors such as international interest and support for the new political dispensation as well as the excitement associated with the transitional period. However, since then national symbols have been caught up with the complex dynamics of intergroup relations within the heterogeneous society. The results could also be an indication that the role of national symbols in building and sustaining nationalism and/or patriotism could be less important.

In contrast to the findings for the cultural concepts and new national symbols, the importance ratings attached to the new South African Constitution, did not support Hypothesis 2. It is noteworthy that respondents of all the groups - including the Afrikaans-speaking Whites - expressed high regard for the South African Constitution. These findings can be seen as a confirmation of the viewpoints of Jones and Smith (2001) that national laws and institutions could play an important role in fostering patriotism and/or nationalism. In the case of South Africa it appears that the Constitution could be the only symbol able to rise above political and ethnocentric interests to foster loyalty among all political, civilizational, racial, cultural and other groupings. It could be hypothesized that changes to the Constitution - and especially changes that have 
implications for the position of particular ethnic or cultural groups - could have serious implications for national unity in South Africa.

The multinational character of South African society according to the typification of Kymlicka (1995) was confirmed by the responses on the question related to consciousness of membership of a distinctive community. The results point to the fact that certain groups in South Africa — and Afrikaans-speaking Whites, Indians and Shangaan/Tsongaspeaking African Blacks in particular - have a strong sense of their uniqueness and distinctiveness as a group.

Hypothesis 3 was also partly supported and partly not supported. The results confirmed this hypothesis in the sense that respondents with high levels of consciousness of being members of a distinctive community attached significantly less importance to the symbols and/or cultural concepts investigated. It appears that groups with high levels of consciousness of their own uniqueness resist the pressure of nation-building strategies to succumb their identity and culture to the ideal of national unity as emphasized in the new national symbols. In the case of groups such as Afrikaans-speaking Whites and Indians with non-African cultures it is also unlikely that they will adopt Africanism as propagandized in the concept of an African Renaissance. In fact, it is highly probable that these groups will resist any Jacobinistic nation-building attempts with an emphasis on unity at the expense of the acknowledgement of diversity. Sincretistic nation-building could therefore be a better option in multinational countries such as South Africa (Hanf, 1989).

However, the results of an analysis of variance with pride in being a South African as dependent variable did not support Hypothesis 3 as no significant differences were found between the three options regarding consciousness of membership of a distinctive community. This finding could be perceived as a confirmation of Kymlicka's (1995) viewpoint that national minorities could still have strong feelings of loyalty or territorial allegiance to their country. One of the reasons could be that national minorities such as Afrikaans-speaking Whites still perceive South Africa as their ethnic and/or cultural homeland. Loyalty to the country can therefore not be ascribed to the fact that they embrace national unity, but rather to an ethnic interpretation of nationalism (Heaven et al., 2000). Another explanation could be that, according to the viewpoints of Jones and Smith (2001), civic elements of nationalism such as loyalty to the Constitution do play an important role in promoting some kind of patriotism and loyalty to the larger political community.

\section{Conclusion}

In conclusion, the findings of this study could serve as a warning against indiscriminate attempts towards nation-building and the promotion of a supra-national identity and culture to the detriment of subnational cultures and identities. Especially in heterogeneous societies where at least some groups attach high value to their unique culture and identity, the acknowledgement and accommodation of diversity could be a better option to promote enduring peace (Degenaar, 1994; Horowitz, 1985, 1991). In accordance with the viewpoints of Venter (1999), patriotism based on loyalty towards a widely accepted constitution based on a Bill of Rights could also be a better option to develop loyalty towards the political community in deeply divided societies such as South Africa.

The results furthermore point to the complexity of governance and promoting peace and national unity in heterogeneous societies. More research in diverse and deeply divided 
societies is needed to understand the impact of national symbols and institutions for various groups as well as for the population of the nation-state as a whole.

\section{References}

African National Congress (ANC). (1997a). Nation-formation and nation building: The national question in South Africa Retrieved May 20, 2005 from http://www.anc.org.za/ancdocs/discussion/nation.html

African National Congress (ANC). (1997b). All power to the people! Building on the foundation for a better life Retrieved May 20, 2005 from http://www.anc.org.za/ancdocs/discussion/strat97.html

Arts \& Culture. (n.d.) National symbols \& heritage. Retrieved July 27, 2005 from http://www.sahistory.org.za/ pages/artsmediaculture/pages/national-symbols/anthem.htm

Bauman, Z. (1998). Globalization: The human consequences. Cambridge: Polity.

Bornman, E., \& Olivier, J. (2000). Patterns of social identification in the post-apartheid South Africa. Paper presented at the Fifteenth International Congress of the International Association for Cross-Cultural Psychology, Pultusk, Poland.

Coetzee, J., \& Wood, G. (1993). Understanding group formation amid eroding identities and neotribalism: Alternative narratives. Acta Academia, 25(2\&3), 65-91.

Constitution of the Republic of South Africa 1996. (n.d.). Retrieved July 27, 2005 from http://www.polity.org.za/ $\mathrm{html} /$ govdocs/constitution/saconst.html?rebookmark $=1$

Degenaar, J. (1994). Beware of nation-building discourse. In N. Rhoodie, \& I. Liebenberg (Eds.), Democratic nation-building in South Africa (pp. 23-30). Pretoria: HSRC.

Habib, A. (1997). South Africa - the Rainbow Nation and prospects for consolidating democracy. African Journal of Political Science, 2(2), 15-37.

Hanf, T. (1989). The prospects of accommodation in communal conflicts: A comparative study. In H. Giliomee, \& L. Schlemmer (Eds.), Negotiating South Africa's future (pp. 89-113). Johannesburg: University of the Witwatersrand, Centre for Policy Studies.

Heaven, P. C. L., Stones, C., Simbayi, L., \& Le Roux, A. (2000). Human values and social identities among samples of White and Black South Africans. International Journal of Psychology, 35(1), 67-72.

Horowitz, D. L. (1985). Ethnic groups in conflict. Berkeley, CA: University of California Press.

Horowitz, D. L. (1991). A democratic South Africa? Constitutional engineering in a divided society. Berkeley: University of California Press.

Human Sciences Research Council. (1987). The South African society: Realities and future prospects (Contributions to Ethnic Studies, Number 21). Westport, CT: Greenwood.

Huntington, S. P. (1996). The clash of civilisations and the remaking of world order. New York: Simon and Schuster.

Jones, F. L., \& Smith, P. (2001). Diversity and commonality in national identities: An exploratory analysis of cross-national patterns. Journal of Sociology, 37(1), 45-63.

Kymlicka, W. (1995). Multicultural citizenship: A liberal theory of minority rights. Oxford: Clarendon.

Liebenberg, I., \& Duvenhage, P. (1996). Can the deep political divisions of South African society be healed? A philosophical and political perspective. Politeia, 15(1), 48-62.

Malan, C. W. (1998). Popular culture and the quest for a rainbow identity. Unpublished document.

Mattes, R. B. (1995). The election book: Judgment and choice in South Africa's 1994 election. Cape Town: Public Information Centre, IDASA.

Mattes, R. B. (1999). Hypotheses on identity and democracy: Community, regime, institutions and citizenship. In S. Bekker, \& R. Prinsloo (Eds.), Identity? Theory, politics, history (pp. 151-180). Pretoria: Human Sciences Research Council.

Möller, V., Dickow, H., \& Harris, M. (1999). South Africa's "Rainbow People", national pride and happiness. Social Indicators Research, 47, 245-280.

National symbols of the Republic of South Africa. (n.d.). Retrieved July 27, 2005 from http://www.saembassyjakarta.or.id/symbols.html

South African Government Information. (n.d.). Retrieved August 27, 2005, from http://www.info.gov.za/ aboutgovt/symbols/flag.htm

Statistics South Africa (SSA). (n.d.). Census 2001. Retrieved August 2, 2005 from http://www.statssa.gove.za/ census01/nationaltreasury/dialog/includes/StatsCouncil.htm

Venter, A. (1999). Nasionale identiteitsvraagstukke in postapartheid-Suid-Afrika (National identity issues in postapartheid South Africa). Tydskrif vir Geesteswetenskappe, 39(1), 22-38. 